\title{
Demonstration of a Role for Insulin in the Regulation of Leptin in Lactating Dairy Cows ${ }^{1}$
}

\author{
S. S. Block, ${ }^{\star}$ R. P. Rhoads, ${ }^{\star}$ D. E. Bauman, ${ }^{\star}$ R. A. Ehrhardt, ${ }^{\star}$ \\ M. A. McGuire, ${ }^{*}$ B. A. Crooker, $\dagger$ J. M. Griinari, ${ }^{*}$ T. R. Mackle, ${ }^{\star}$ \\ W. J. Weber, $\dagger$ M. E. Van Amburgh, ${ }^{\star}$ and Y. R. Boisclair* \\ *Department of Animal Science, Cornell University, Ithaca, NY 14853 \\ †University of Minnesota, St. Paul 55108
}

\begin{abstract}
In lactating dairy cows, the onset of negative net energy balance (EB) at parturition causes a reduction in plasma leptin and is also associated with increased concentration of growth hormone $(\mathrm{GH})$ and decreased concentration of insulin. These observations raise the possibility that opposite changes in plasma insulin and GH are partly responsible for reduced plasma leptin. To test this hypothesis, we first examined the effects of undernutrition without the confounding influence of parturition by using late lactating dairy cows fed $120 \%$ of their nutrient requirements or restricted to $33 \%$ of maintenance requirements. Plasma leptin was reduced within $24 \mathrm{~h}$ of feed restriction, and was associated with increased plasma $\mathrm{GH}$ and decreased plasma insulin. Complete food deprivation for $48 \mathrm{~h}$ caused similar changes in the plasma concentration of leptin. To determine if an elevation in $\mathrm{GH}$ is responsible for the fall in plasma leptin, dairy cows were treated with excipient or bovine somatotropin in early lactation or in late lactation. Growth hormone treatment had no significant effect on plasma leptin irrespective of stage of lactation. Finally, the effects of insulin were studied by performing euglycemic hyperinsulinemic clamps in midlactating dairy cows. After $96 \mathrm{~h}$ of hyperinsulinemia, plasma leptin was increased significantly. These data indicate that insulin regulates plasma leptin in lactating dairy cows. They also suggest that, in undernourished lactating dairy cows, reduced plasma insulin could account for a portion of the decline in plasma leptin but that elevated plasma GH is unlikely to have a major effect.
\end{abstract}

(Key words: leptin, insulin, GH, lactation, undernutrition)

\footnotetext{
Received January 17, 2003.

Accepted June 7, 2003.

Corresponding author: Y. R. Boisclair; e-mail: yrb1@cornell.edu.

${ }^{1}$ Supported by the National Research Initiative Competitive Grant Program, USDA CREES 00-35206-9352 (to Y. R. B.) and by the Cornell University Agricultural Experiment Station.
}

\begin{abstract}
Abbreviation key: AGRP = agouti-related peptide, BCAA = branched chain amino acids, EB = energy balance, $\mathbf{G H}=$ growth hormone, $\mathbf{N P Y}=$ neuropeptide $\mathrm{Y}$, POMC = proopiomelanocortin, RIA = radioimmunoassay, $\mathbf{W A T}=$ white adipose tissue.
\end{abstract}

\section{INTRODUCTION}

Leptin is a $16-\mathrm{kDa}$ protein hormone synthesized almost exclusively by white adipose tissue (WAT) (Ahima and Flier, 2000; Ingvartsen and Boisclair, 2001; Spiegelman and Flier, 2001). In ruminants and other animals, leptin synthesis is regulated positively by adiposity, and negatively by undernutrition (Ahima and Flier, 2000; Ingvartsen and Boisclair, 2001). Current evidence indicates that leptin is involved in the regulation of energy homeostasis. Thus, systemic or intracerebroventricular administration of leptin is associated with reduced feed intake and increased energy expenditure (Henry et al., 1999; Ahima and Flier, 2000; Morrison et al., 2001). In contrast, the low concentration of plasma leptin during undernutrition induces increased appetite as well as neuroendocrine adaptations responsible for metabolic adaptations and energy conservation (Ahima et al., 1996; Schwartz et al., 2000). Leptin elicits these actions by acting primarily on neurons located in the arcuate, ventromedial, and dorsomedial hypothalamic nuclei. These neuronal regions have a high concentration of $\mathrm{Ob}-\mathrm{Rb}$, the fully competent signaling form of the leptin receptor (Ahima and Flier, 2000; Schwartz et al., 2000). Leptin also acts directly on a limited number of peripheral cell types, including pancreatic $\beta$-cells, intestinal and immune cells (Emilsson et al., 1997; Lord et al., 1998; Morton, 1999).

Recently, we demonstrated that the plasma concentration of leptin is reduced abruptly around the time of parturition in lactating dairy cows (Block et al., 2001). The periparturient reduction in plasma leptin precedes significant depletion of lipid reserves, but coincides with the onset of negative energy balance (Block et al., 2001). The onset of negative energy balance around parturition was also associated with decreased plasma 
insulin and increased plasma growth hormone (GH) (Block et al., 2001), suggesting that both hormones could mediate a portion of the effect of energy balance on plasma leptin. Evidence supporting this idea exists in rodent and humans, with insulin increasing and GH decreasing plasma leptin (Miyakawa et al., 1998; Elimam et al., 1999; Ahima and Flier, 2000). However, the role of insulin and $\mathrm{GH}$ in regulating plasma leptin has not been examined in dairy cattle.

Therefore, the objectives of the present study were twofold. First, we determined whether changes in the plane of nutrition are capable of regulating the plasma concentration of leptin in dairy cows during established lactation. Second, we determined whether insulin or GH could be involved in mediating the effects of nutrition on plasma leptin. Our results implicate insulin as an important regulator of plasma leptin during lactation.

\section{MATERIALS AND METHODS}

\section{Animals and Design}

Six different experiments were performed on multiparous Holstein cows at Cornell University $(\mathrm{n}=5)$ or at the University of Minnesota $(\mathrm{n}=1)$. All experimental procedures were conducted with the approval of the local Institutional Animal Care and Use Committee (Cornell University or University of Minnesota). Milk yields were collected at each milking, between 0600 and 0700, and between 1800 and 1900 h. Protein, fat, and lactose content of milk were determined by infrared analysis (Dairy One Cooperative Inc., Ithaca, NY or Minnesota State DHIA, Zumbrota, MN). Unless otherwise mentioned, blood samples were obtained from indwelling jugular venous catheters; plasma was prepared by the addition of heparin $(100 \mathrm{U} / \mathrm{ml}$ blood $)$ and then centrifuged. Plasma was stored at $-20^{\circ} \mathrm{C}$ until analyzed. Details specific to each experiment are as follows.

Feed restriction study. Four nonpregnant Holstein cows, averaging $702 \pm 22$ (SE) kg of BW, were used in late lactation ( $507 \pm 60 \mathrm{DIM})$. A single TMR containing $1.54 \mathrm{Mcal} \mathrm{NE}_{\mathrm{L}}$ and $157 \mathrm{~g}$ of CP/kg DM was fed throughout the study. Cows were fed amounts corresponding to $120 \%$ of their predicted energy requirements for a period of $8 \mathrm{~d}$ (NRC, 1989). Then the plane of nutrition was restricted to $33 \%$ of maintenance requirements for 3 consecutive days. During both periods, the daily allowance was distributed into 12 bihourly meals with water available at all times. On the first day of undernutrition (d 0), blood was obtained immediately before the initiation of feed restriction at $0900 \mathrm{~h}$. Blood samples were also obtained between 0900 and $1000 \mathrm{~h}$ before $(\mathrm{d}$
$-1)$ and after the initiation of feed restriction $(d+1,+2$, and +3 ).

Fasting. A second study originally designed to evaluate the effect of fasting on components of the circulating IGF system was also used (McGuire et al., 1995). Briefly, 4 cows $(649 \pm 14 \mathrm{~kg} \mathrm{BW})$ in midlactation (175 \pm 3 d postpartum) were fed $120 \%$ of predicted energy requirements for 6 consecutive days. The diet consisted of a TMR (1.53 Mcal NE $\mathrm{N}_{\mathrm{L}}$ and $165 \mathrm{~g}$ of $\mathrm{CP} / \mathrm{kg} \mathrm{DM}$ ) fed once daily at $0800 \mathrm{~h}$. Twenty-four hours after the last feeding, a 48-h period of fasting was initiated. Water was available at all times throughout the experiment. Blood samples were obtained before $(-18,-16,-2$, and $-1 \mathrm{~h})$ and after $(+36,+40,+44$, and $+48 \mathrm{~h})$ initiation of fasting at $0800 \mathrm{~h}(0 \mathrm{~h})$.

GH studies. The first study utilized 4 cows in late lactation (described above in feed restriction study). They were used in a single reversal design with 4-d periods separated by a 2 -d interval. Treatments were daily intramuscular injection of saline or $40 \mathrm{mg}$ of recombinant bST (CP104301, Lot 96J-B5128-002, Monsanto Inc., St. Louis) at $0900 \mathrm{~h}$. During both periods cows were fed a fixed amount of TMR (1.54 Mcal NE and $157 \mathrm{~g}$ of CP/ $\mathrm{kg} \mathrm{DM}$ ) corresponding to $120 \%$ of energy requirements estimated during a 7-d preliminary period. Blood samples were obtained every hour between 1000 and $1500 \mathrm{~h}$ on the $\mathrm{d} 4$ of treatment.

The second study was conducted at the University of Minnesota with 12 cows in early lactation $(569 \pm 6 \mathrm{~kg}$ $\mathrm{BW}$ ). Starting on d 15 of lactation, cows ( $\mathrm{n}=6 \mathrm{per}$ treatment) received either daily intramuscular injection of saline or $14 \mathrm{mg}$ of bST between 1000 and 1100 h (lot 12-77-001, Pharmacia and Upjohn, Inc., Kalamazoo, MI) for 7 consecutive days. During the treatment period, cows were allowed ad libitum access to a TMR containing $1.7 \mathrm{Mcal}$ of $\mathrm{NE}_{\mathrm{L}}$ and $157 \mathrm{~g}$ of $\mathrm{CP} / \mathrm{kg} \mathrm{DM}$. Blood samples were obtained between 0900 and 1000 $\mathrm{h}$ before $(\mathrm{d}-8,-1$, and 0$)$ and after $(\mathrm{d}+1,+2$, and +6$)$ initiation of treatment. They were obtained by coccygeal venipuncture into evacuated collection tubes (Becton Dickinson, Franklin Lakes, NJ) containing NaFlKoxalate.

Insulin studies. Two hyperinsulinemic-euglycemic clamp studies were used. Experimental details and results pertaining to the effect of insulin on mammary protein synthesis were reported previously (Griinari et al., 1997; Mackle et al., 1999).

In the first study, 5 cows averaging $558 \pm 23 \mathrm{~kg} \mathrm{BW}$ and $184 \pm 19$ DIM were used (Griinari et al., 1997). Throughout the study, cows were fed a TMR (1.63 Mcal $\mathrm{NE}_{\mathrm{L}}$ and $166 \mathrm{~g}$ of $\left.\mathrm{CP} / \mathrm{kg} \mathrm{DM}\right)$ ad libitum and semicontinuously (every $2 \mathrm{~h}$ ). They were used in a crossover design with a 12-d period separated by a 4-d interval. Treatment consisted of either abomasal infusion of wa- 
ter $(6 \mathrm{~L} / \mathrm{d})$ or protein supplement $(0.5 \mathrm{~kg}$ of sodium caseinate in $6 \mathrm{~L}$ of water/d). Each 12-d period was divided into sequential 96 -h periods of acclimatization, basal measurements, and euglycemic hyperinsulinemia. Hyperinsulinemia was achieved by intrajugular infusion of bovine insulin ( $1 \mu \mathrm{g} / \mathrm{kg}$ BW per hour; Sigma Chemical Co., St. Louis, MO); the concentration of blood glucose was determined every hour and maintained to that observed during the basal period by varying the rate of intrajugular infusion of a 50\% glucose monohydrate solution. Four individual blood samples were obtained during the basal period $(-72,-48,-24$ and -1 $\mathrm{h}$ relative to initiation of insulin infusion), and at the end of the period of euglycemic hyperinsulinemia $(+84$, $+88,+92$, and $+96 \mathrm{~h}$ ).

In the second hyperinsulinemic-euglycemic study, 4 cows averaging $641 \pm 40 \mathrm{~kg} \mathrm{BW}$ and $220 \pm 11$ DIM were used (Mackle et al., 1999). Feeding, management, and design were exactly as described for the first study, except that cows received an additional supply of amino acids that were administered abomasally and involved $0.5 \mathrm{~kg}$ of sodium caseinate supplemented with a mixture of branched chain amino acids (BCAA; $33 \mathrm{~g}$ of LLeu, $25 \mathrm{~g}$ of L-Ile, and $31 \mathrm{~g}$ of L-Val). Individual blood samples were obtained at the end of the basal period $(-36,-24,-12$, and $-1 \mathrm{~h}$ relative to the initiation of insulin infusion) and at the end of the period of euglycemic hyperinsulinemia $(+72,+80,+88$, and $+94 \mathrm{~h})$.

\section{Analysis of Metabolites and Hormones}

During hyperinsulinemic-euglycemic clamps, blood glucose was determined using an automatic analyzer (Yellow Springs Instrument; Yellow Springs, OH). Plasma glucose was measured by the glucose oxidase method and NEFA by the acyl-CoA synthetase/oxidase method as described previously (Boisclair et al., 1994). Plasma leptin was assayed by a double-antibody bovine radioimmunoassay (RIA) (Ehrhardt et al., 2000). This assay is based on a primary rabbit antibody raised against recombinant bovine leptin and a secondary goat antibody raised against rabbit $\gamma$-globulin. Recombinant bovine leptin was used for iodination and standards. A solid-phase commercial RIA (Diagnostic Products Corp., Los Angeles, CA) was used to measure insulin in the study examining effects of $\mathrm{GH}$ in early lactation. For other experiments, plasma insulin was assayed with a double antibody RIA based on a primary antibody raised against porcine insulin in guinea pigs (Linco Research Inc., St. Charles, MO) and on bovine insulin (lot 615-70N-80; Lilly Research Laboratories, Greenfield, IN) for iodination and standards. A double antibody RIA was also used to assay plasma GH. Primary antibody was raised in rabbits against ovine $\mathrm{GH}$ (supplied by the National Hormone and Pituitary Program, Torrence, CA) and bovine GH (Lot 12-77-001; Pharmacia \& Upjohn Inc. Kalamazoo, MI) was used for iodination and standards. Inter- and intraassay CV for all assays averaged less than 7 and 9\%, respectively.

\section{Calculations and Statistical Analysis}

Body weights were used to estimate individual maintenance requirements (NRC, 1989). Milk energy outputs were estimated from daily milk yield and composition. Net energy balance (EB) was then estimated as the difference between energy intake and energy expenditures (maintenance and milk energy) as described previously (McGuire et al., 1995; Block et al., 2001). Three and one-half percent FCM yields were calculated according to equations described in (NRC, 1989).

Data were analyzed by repeated measure models using SAS (SAS Institute, Cary, NC). For the undernutrition study, the linear model accounted for time as the fixed effect and animal as the random effect. When the effect of time was significant $(P<0.05)$, variation accounted for by the plane of nutrition was examined with the following preplanned orthogonal contrasts: 1) Nutrition (NUTRITION, $d-1$ and 0 vs. $d+1,+2$ and +3 ); 2) Time of undernutrition (UNDER, $d+3$ vs. $d+1$ ); 3) Time of normal feeding (FED, d -1, vs. d 0).

For all other studies, blood samples were obtained at steady state as indicated by the absence of time related effects on measured variables. Therefore, means were calculated for each variable and used in a mixed model accounting for the effect of treatment as the fixed effect (i.e., either fed vs. underfed, saline vs. GH, or insulin and protein) and animal and period as the random effect. In the study examining the effect of GH in early lactation, data collected prior to treatment were used as a covariate. Treatment effects were considered significant at $P<0.05$ level.

\section{RESULTS}

\section{Feed Restriction}

Restricting lactating dairy cows to $33 \%$ of their maintenance requirements caused the onset of negative net $\mathrm{EB}$ and a reduction in the yield of 3.5\% FCM (Table 1, $P<0.001)$. The progressive decline in milk yield during undernutrition attenuated the estimated energy deficit $(P<0.001)$. Underfeeding caused an immediate increase in the plasma concentration of NEFA and a decrease in the plasma concentration of glucose $(P<$ 0.001). Effects of undernutrition increased over time for NEFA $(P<0.001)$, but not for glucose. Underfeeding caused a decrease in the plasma concentration of insulin $(P<0.01)$ and an elevation in the plasma concentra- 
Table 1. Changes in energy-related variables in response to underfeeding.

\begin{tabular}{|c|c|c|c|c|c|c|c|c|c|}
\hline \multirow[b]{2}{*}{ Variable } & \multicolumn{5}{|c|}{ Days relative to underfeeding ${ }^{1}$} & \multirow[b]{2}{*}{$\mathrm{SE}$} & \multicolumn{3}{|c|}{ Significance of contrast ${ }^{2}$} \\
\hline & -1 & 0 & +1 & +2 & +3 & & NUTRITION & FED & UNDER \\
\hline \multicolumn{10}{|l|}{ Performance } \\
\hline Dry matter intake, $\mathrm{kg} / \mathrm{d}^{3}$ & 17.2 & 17.0 & 2.1 & 2.1 & 2.1 & & & & \\
\hline Milk Yield, kg/d ${ }^{4}$ & 22.0 & 22.3 & 14.8 & 12.1 & 11.7 & 0.5 & $<0.001$ & NS & $<0.001$ \\
\hline Energy Balance, Mcal/d & 3.3 & 2.9 & -22.1 & -16.9 & -14.9 & 0.7 & $<0.001$ & NS & $<0.001$ \\
\hline \multicolumn{10}{|l|}{ Metabolites } \\
\hline Glucose, mg/dl & 58 & 57 & 55 & 49 & 52 & 2 & $<0.001$ & NS & NS \\
\hline NEFA, $\mu \mathrm{M}^{5}$ & 126 & 130 & 478 & 1078 & 909 & 106 & $<0.001$ & NS & $<0.001$ \\
\hline
\end{tabular}

${ }^{1}$ Multiparous cows $(\mathrm{n}=4)$ were studied before $(\mathrm{d}-1$ and 0$)$ and after underfeeding $(\mathrm{d}+1,+2$, and +3$)$. Cows were offered $120 \%$ of nutrient requirements before underfeeding and $33 \%$ of maintenance energy requirements during underfeeding.

${ }^{2}$ Linear contrasts were: NUTRITION ( $\mathrm{d}-1$ and 0 vs. $\mathrm{d}+1,+2$, and +3 ); FED, time of normal feeding ( $\mathrm{d}$ -1 vs. $d 0)$; and UNDER, time of undernutrition $(d+1$ vs. $d+3)$. Type I error probability where NS = nonsignificant, $P>0.05$.

${ }^{3}$ No statistics were performed because feed intake was fixed.

${ }^{4}$ Expressed as 3.5\% FCM.

${ }^{5}$ NEFA, nonesterified fatty acids.

tion of GH $(P<0.001$; Figure 1$)$ that tended to increase over time $(P<0.1)$. The plasma concentration of leptin fell by $23 \%$ within $24 \mathrm{~h}$ after the initiation of underfeeding $(P<0.0001)$ but did not decrease further over the next $48 \mathrm{~h}$ (Figure 1).

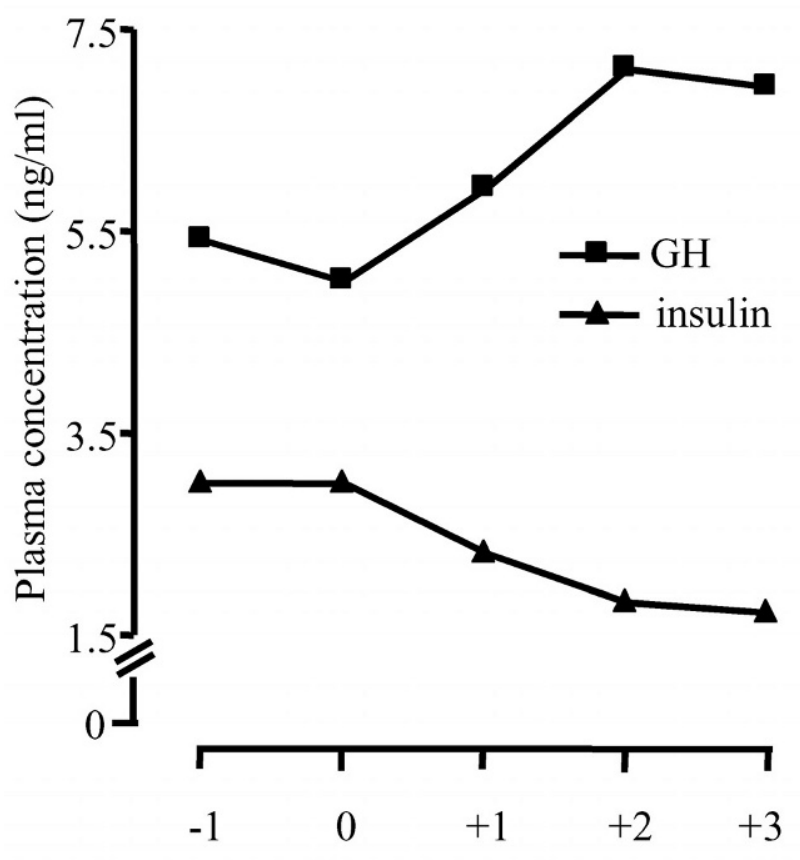

Days of underfeeding
Next we determined whether the negative effect of underfeeding on plasma leptin was exacerbated by complete food deprivation. After $48 \mathrm{~h}$ of fasting, plasma leptin was reduced by $26 \%$ (fed vs. fasted, $2.7 \pm 0.2$ vs. $2.0 \pm 0.2 \mathrm{ng} / \mathrm{ml} ; P<0.05)$. Again this reduction was

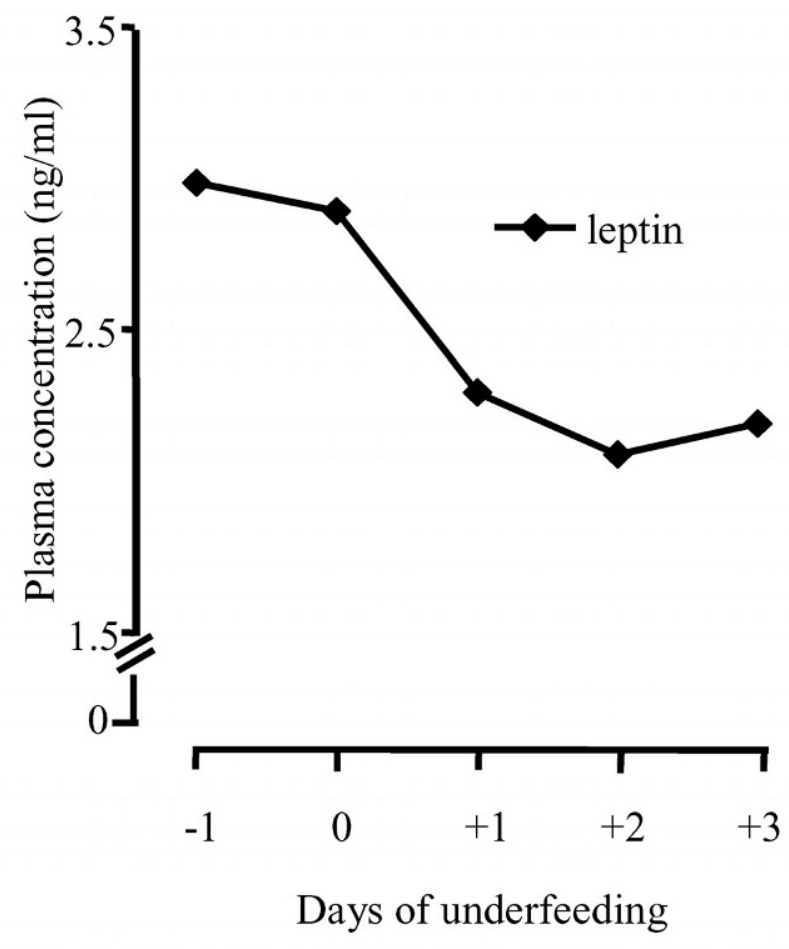

Figure 1. Changes in plasma concentration of GH, insulin and leptin in response to undernutrition. Four multiparous dairy cows were studied when offered $120 \%$ of energy requirements $(\mathrm{d}-1$ and 0$)$ and after reducing the plane of nutrition to $33 \%$ of calculated maintenance energy requirements $(\mathrm{d}+1,+2$, and +3$)$. Plasma GH was elevated by undernutrition $(P<0.001)$ whereas plasma concentration of insulin and leptin were decreased $(P<0.01$ and $P<0.001$, respectively). Pooled standard errors were $0.5 \mathrm{ng} / \mathrm{ml}$ for GH, $0.4 \mathrm{ng} / \mathrm{ml}$ for insulin, and $0.2 \mathrm{ng} / \mathrm{ml}$ for leptin. 
Table 2. Plasma metabolites and hormones after administration of rbST in late lactation.

\begin{tabular}{lrrrl}
\hline & \multicolumn{2}{c}{ Treatment $^{1}$} & & \\
\cline { 2 - 3 } Plasma variable & Saline & bST & SE & Significance $^{2}$ \\
\hline Metabolites & & & & \\
$\quad$ Glucose, $\mathrm{mg} / \mathrm{dl}$ & 61 & 61 & 2 & $\mathrm{NS}$ \\
$\quad$ NEFA, $\mu \mathrm{M}^{3}$ & 117 & 210 & 10 & $<0.001$ \\
Hormones & & & & \\
$\quad$ Growth hormone, ng/ml & 5.6 & 37.4 & 5.5 & $<0.01$ \\
Insulin, $\mathrm{ng} / \mathrm{ml}$ & 2.5 & 3.9 & 1.2 & $\mathrm{NS}$ \\
Leptin, ng/ml & 2.8 & 2.5 & 0.1 & $\mathrm{NS}$ \\
\hline
\end{tabular}

${ }^{1}$ Multiparous dairy cows $(\mathrm{n}=4)$ were injected at $0900 \mathrm{~h}$ with either saline or bST $(40 \mathrm{mg} / \mathrm{d})$ for 4 consecutive days. Analyses were performed on blood samples collected on the fourth day of treatment between 1000 and $1500 \mathrm{~h}$.

${ }^{2}$ Type I error probability where NS = nonsignificant, $P>0.05$.

${ }^{3} \mathrm{NEFA}$, nonesterified fatty acids.

associated with increased plasma concentrations of $\mathrm{GH}$ and NEFA and decreased concentrations of insulin and glucose (McGuire et al., 1995). Therefore, despite the state of hypoleptinemia prevailing in lactating dairy cows, undernutrition remains capable of reducing plasma leptin. This reduction coincides with decreasing plasma concentrations of insulin and increasing plasma concentrations of $\mathrm{GH}$.

\section{Effect of Short-Term GH Treatment}

To determine whether plasma GH could mediate the negative effects of undernutrition on plasma leptin, cows in late lactation were treated with recombinant bST. After $4 \mathrm{~d}$ of treatment, bST treatment caused a 7 -fold increase in plasma GH (Table $2, P<0.01$ ) and increased milk yield by $26 \%$ (19.9 vs. $25.1 \mathrm{~kg} / \mathrm{d}, P<$ 0.02). Milk composition was analyzed for only two of the cows during this experiment, preventing statistical analysis of the effect of bST on EB. In these two cows, the estimated EB was reduced by bST, but did not become negative. Bovine somatotropin treatment had no significant effects on plasma concentrations of glucose or insulin, but caused a small increase in the concentration of NEFA (Table 2). The elevation in plasma concentrations of GH only tended to reduce the plasma concentration of leptin, however $(P=0.14)$.

To determine whether the effects of GH differ according to stage of lactation, a second study using cows in early lactation was conducted. Administration of bST had no effect on daily feed intake (control vs. bST, 16.3 \pm 1.1 vs. $15.0 \pm 1.1 \mathrm{~kg} / \mathrm{d}$ ), $3.5 \% \mathrm{FCM}$ yield (control vs. bST, $37.0 \pm 2.0$ vs. $38.8 \pm 2.0 \mathrm{~kg} / \mathrm{d}$ ) or energy balance (control vs. bST, $-8.8 \pm 1.2$ vs. $-11.4 \pm 1.2 \mathrm{Mcal} / \mathrm{d}$ ). Similarly, bST had no effect on plasma leptin, insulin,
Table 3. Plasma metabolites and hormones after administration of rbST in early lactation.

\begin{tabular}{|c|c|c|c|c|}
\hline \multirow[b]{2}{*}{ Variables } & \multicolumn{2}{|c|}{ Treatment $^{1}$} & \multirow[b]{2}{*}{$\mathrm{SE}$} & \multirow[b]{2}{*}{ Significance $^{2}$} \\
\hline & Saline & $\mathrm{bST}$ & & \\
\hline \multicolumn{5}{|l|}{ Metabolites } \\
\hline Glucose, $\mathrm{mg} / \mathrm{dl}$ & 47 & 47 & 2 & NS \\
\hline NEFA, $\mu \mathrm{M}^{3}$ & 478 & 563 & 60 & NS \\
\hline \multicolumn{5}{|l|}{ Hormones } \\
\hline IGF-I, ng/ml & 52 & 51 & 4 & NS \\
\hline Insulin, $\mathrm{ng} / \mathrm{ml}$ & 0.11 & 0.08 & 0.02 & NS \\
\hline Leptin, ng/ml & 2.7 & 2.7 & 0.1 & NS \\
\hline
\end{tabular}

${ }^{1}$ Multiparous dairy cows were injected between 1000 and $1100 \mathrm{~h}$ with either saline $(\mathrm{n}=6)$ or $\mathrm{bST}(14 \mathrm{mg} / \mathrm{d}, \mathrm{n}=6)$ for 8 consecutive days. Analysis were performed on blood samples collected between 0900 and 1000 on $d+1,+2$, and +6 of treatment (d 16, 17, and 21 of lactation).

${ }^{2}$ Type I error probability where NS $=$ nonsignificant, $P>0.05$.

${ }^{3} \mathrm{NEFA}$, nonesterified fatty acids.

glucose or NEFA concentration (Table $3 ; P>0.1$ ). These data suggest that $\mathrm{GH}$ does not exert major effects on plasma leptin in early or late lactating dairy cows.

\section{Effect of Insulin}

To determine the effects of insulin, plasma concentrations of leptin were measured over the last 12 to $24 \mathrm{~h}$ of 96-h periods of basal measurements or hyperinsulinemic euglycemia. In the first experiment, these measurements were performed in the presence or absence of abomasal infusion of casein (Griinari et al., 1997). During the basal period, protein supplementation had no effect on either plasma insulin (1.5 vs. $1.6 \mathrm{ng} / \mathrm{ml}$ ) or glycemia ( 49.7 vs. $49.2 \mathrm{mg} / \mathrm{dl}$ ). The increase in plasma insulin ( 4.3 fold) and the degree of glycemic control $( \pm$ $10 \%$ of basal levels) were similar during the clamps, irrespective of protein supplementation.

Hyperinsulinemia increased plasma leptin (experiment 1; Table 4), but this effect tended to be greater during the period of protein supplementation (Ins $\times$ Protein; $P=0.11$ ). The greater insulin-dependent response during the period of casein infusion was associated with a smaller reduction in feed intake (water vs. casein 6.7 vs. $1.4 \mathrm{~kg} / \mathrm{d} ; P<0.05$ ). Consequently, hyperinsulinemia had no effect on estimates of EB corrected for infused casein and glucose in the absence of protein supplementation (-Ins vs. + Ins, +5.1 vs. +5.3 $\mathrm{Mcal} / \mathrm{d}$ ), but improved EB during the period of protein supplementation ( - Ins vs. + Ins, +4.6 vs. $+10.7 \mathrm{Mcal} / \mathrm{d}$ ).

To clarify this issue, we conducted a second study in which hyperinsulinemia caused identical modest reductions in feed intake $(1.8 \mathrm{~kg} / \mathrm{d})$ irrespective of protein supplementation (either water or casein + BCAA) and resulted in similar positive estimates of net EB (Mackle et al., 1999). Hyperinsulinemia caused a similar in- 
Table 4. Effects of insulin and protein on the plasma concentration of leptin.

\begin{tabular}{|c|c|c|c|c|c|c|c|c|}
\hline & \multicolumn{2}{|c|}{ Water } & \multicolumn{2}{|c|}{ Protein } & \multirow[b]{2}{*}{$\mathrm{SE}$} & \multicolumn{3}{|c|}{ Significance $^{3}$} \\
\hline & $-\operatorname{Ins}$ & $+\operatorname{Ins}$ & - Ins & $+\operatorname{Ins}$ & & Ins & Protein & Ins $\times$ Protein \\
\hline & \multicolumn{8}{|c|}{ — Plasma leptin $(\mathrm{ng} / \mathrm{ml})-$} \\
\hline Experiment $1^{1}$ & 2.4 & 2.7 & 2.3 & 2.8 & 0.1 & $<0.001$ & NS & 0.11 \\
\hline Experiment $2^{2}$ & 2.4 & 3.3 & 2.5 & 3.4 & 0.2 & $<0.001$ & NS & NS \\
\hline
\end{tabular}

${ }^{1}$ Five lactating dairy cows received daily abomasal infusion of water $(6 \mathrm{~L})$ with or without $0.5 \mathrm{~kg}$ sodium caseinate for $12 \mathrm{~d}$ (Griinari et al., 1997). Each period was divided into sequential $96 \mathrm{~h}$ periods of acclimatization, basal measurements and euglycemic hyperinsulinemia. Plasma concentrations of leptin were measured over the last $24 \mathrm{~h}$ of the basal periods (-Ins) and over the last $12 \mathrm{~h}$ of euglycemic-hyperinsulinemia (+Ins).

${ }^{2}$ Four lactating dairy cows received daily abomasal infusion of water $(6 \mathrm{~L})$ supplemented with or without $0.5 \mathrm{~kg}$ sodium caseinate and branched-chain amino acids (33 g L-Leu, $25 \mathrm{~g}$ of L-Ile and $31 \mathrm{~g} \mathrm{~L}-\mathrm{Val}$ ) (Mackle et al., 2000). Each period was divided into sequential $96 \mathrm{~h}$ periods of acclimatization, basal measurements and euglycemic hyperinsulinemia. Plasma concentrations of leptin were measured over the last $36 \mathrm{~h}$ of the basal periods (-Ins) and over the last $24 \mathrm{~h}$ of euglycemic-hyperinsulinemia (+Ins).

${ }^{3}$ Type I error probability where NS = nonsignificant, $P>0.05$.

crease in plasma leptin at both levels of protein (experiment 2, Table 4). Overall, these results indicate that insulin is a positive regulator of plasma leptin in lactating dairy cows and is likely to mediate a portion of the effects of nutrition.

\section{DISCUSSION}

We previously reported that parturition in dairy cows is associated with a reduction in plasma leptin and attributed this reduction to the state of negative EB caused by the initiation of copious milk secretion (Block et al., 2001). This interpretation was based on the close temporal correlations between the fall in plasma leptin and the onset of negative EB, and by higher plasma leptin in dairy cows in which the energy deficit of early lactation was prevented by absence of milk removal. Many changes occur during the periparturient period in addition to the onset of negative EB, including loss of the conceptus and a multitude of metabolic and hormonal adaptations (Bell, 1995; Bauman, 2000). Therefore, we sought to reexamine the effects of undernutrition on plasma leptin without the confounding effects of parturition.

In many mammals, a state of hypoleptinemia exists during lactation (Pickavance et al., 1998; Terada et al., 1998; Kunz et al., 1999). In agreement with these observations, the concentration of plasma leptin is consistently less than $3 \mathrm{ng} / \mathrm{ml}$ in lactating dairy cows, irrespective of the stage of lactation [this study and Block et al. (2001)]. We now show, that despite this state of hypoleptinemia, undernutrition remains a negative regulator of plasma leptin in dairy cows. This agrees with similar effects of undernutrition on plasma leptin in growing and nonlactating mature ruminants (either pregnant or nonpregnant) (Amstalden et al., 2000; Blache et al., 2000; Marie et al., 2001; Thomas et al.,
2001; Garcia et al., 2002). In rodents, fasting decreases plasma leptin, and this decline stimulates the synthesis of orexigenic neuropeptides such as neuropeptide Y (NPY) and agouti-related peptide (AGRP) and decreased the synthesis of anorexigenic neuropeptides such as proopiomelanocortin (POMC). In turn, these central adaptations orchestrate responses required for survival, such as increased appetite and decreased metabolic rate (Ahima and Flier, 2000; Schwartz et al., 2000; Ingvartsen and Boisclair, 2001). Undernutrition also causes increased plasma GH and decreased plasma insulin (McGuire et al., 1995). These changes are thought to coordinate the metabolism of peripheral tissues such as liver, muscle, and adipose tissue (Etherton and Bauman, 1998; Bauman, 2000), and they coincide exactly with the onset of negative EB and the decline in plasma leptin in both periparturient and underfed cows (this study and Block et al., 2001). Thus, changes in circulating concentrations of insulin and GH that are associated with changes in nutritional state could be involved in mediating the decrease in plasma leptin during periods of undernutrition.

Under euglycemic conditions, hyperinsulinemia rapidly increases plasma leptin concentration and abundance of leptin mRNA in WAT of rodents (Saladin et al., 1995). Hyperinsulinemia under euglycemic conditions also increases plasma leptin in humans, but this effect usually requires many hours to become apparent (Kolaczynski et al., 1996; Boden et al., 1997; Askari et al., 2000). In agreement with the delayed response in humans, chronic hyperinsulinemia caused an increase in plasma leptin in the present study, whereas an acute elevation in plasma insulin had no effect in adult wethers (Kauter et al., 2000). One possible confounding factor associated with long-term euglycemic hyperinsulinemia is improved EB resulting from the intravascular delivery of glucose. However, hyperinsulinemia is also 
capable of increasing plasma leptin when feed intake is reduced (experiment 1, water vs. casein; Table 4) (Griinari et al., 1997). Therefore, insulin and/or the insulin-induced increase in uptake of glucose by WAT must be the primary factor stimulating leptin synthesis. This agrees with in vitro studies with bovine and ovine WAT in which insulin increased indices of leptin synthesis (Chilliard et al., 2000; Houseknecht et al., 2000). Finally, we did not measure body condition in our studies, and it is possible that adiposity modulate the ability of insulin to increase plasma leptin. Other issues that remain to be addressed in lactating dairy cows include the time-course of insulin action on plasma leptin, and whether increased mRNA abundance is responsible for increased plasma leptin.

Experimental and theoretical evidence also suggests that $\mathrm{GH}$ could be involved in regulating plasma leptin. Growth hormone is elevated in undernourished cattle and attenuates many effects of insulin under in vitro conditions in ruminant WAT, such as glucose transport, lipogenesis, and leptin synthesis (Etherton and Bauman, 1998; Houseknecht et al., 2000). Growth hormonedeficient humans have higher concentrations of plasma leptin than normal individuals (Florkowski et al., 1996; Elimam et al., 1999; Ahmad et al., 2001), whereas the opposite situation occurs in acromegalic patients (Miyakawa et al., 1998). Growth hormone therapy of GHdeficient individuals normalizes plasma leptin even before significant reductions in adiposity occur (Florkowski et al., 1996; Elimam et al., 1999; Ahmad et al., 2001). Results from a single report suggest inhibition of leptin synthesis when growing cattle are in negative or near zero energy balance and stimulation of leptin synthesis when in positive energy balance (Houseknecht et al., 2000). To directly examine the effect of GH in dairy cattle, we administered bST to early or late lactating dairy cows. Although GH treatment failed to significantly alter plasma leptin at both stages of lactation, closer inspection of the results raises the possibility that $\mathrm{GH}$ can interfere with the effects of insulin. Specifically, GH tended to reduce plasma leptin in late lactation when a numerical increase in plasma insulin was observed. Therefore, additional studies are warranted, particularly in late lactation when GH treatment often leads to increased plasma insulin (Peel and Bauman, 1983). However, during periods of undernutrition when plasma insulin is low, GH appears unlikely to play a major role in reducing plasma leptin.

In summary, our results indicate that insulin is a positive regulator of plasma leptin in lactating dairy cattle when in positive EB. This suggests that reductions in plasma insulin during periods of nutritional deficit could be responsible for mediating a portion of the coincidental fall in plasma leptin. Hyperinsulinemic clamp studies performed in lactating dairy cattle during periods of negative EB (i.e., underfed or in early lactation) are needed to resolve this question.

\section{ACKNOWLEDGMENTS}

Authors thank Ramona Ehrhardt for her help in performing various RIA; we also thank J. W. Lauderdale of Pharmacia and Upjohn, Inc., Kalamazoo, MI, and J. Vicini of Monsanto Co., St. Louis, MO, for providing recombinant bovine somatotropin.

\section{REFERENCES}

Ahima, R. S., and J. S. Flier. 2000. Leptin. Annu. Rev. Physiol. 62:413-437.

Ahima, R. S., D. Prabakaran, C. Mantzoros, D. Qu, B. Lowell, E. Maratos-Flier, and J. S. Flier. 1996. Role of leptin in the neuroendocrine response to fasting. Nature (Lond.) 382:250-252.

Ahmad, A. M., R. Guzder, A. M. Wallace, J. Thomas, W. D. Fraser, and J. P. Vora. 2001. Circadian and ultradian rhythm and leptin pulsatility in adult GH deficiency: Effects of GH replacement. J. Clin. Endocrinol. Metab. 86:3499-3506.

Amstalden, M., M. R. Garcia, S. W. Williams, R. L. Stanko, S. E. Nizielski, C. D. Morrison, D. H. Keisler, and G. L. Williams. 2000. Leptin gene expression, circulating leptin, and luteinizing hormone pulsatility are acutely responsive to short-term fasting in prepubertal heifers: Relationships to circulating insulin and insulin-like growth factor I(1). Biol. Reprod. 63:127-133.

Askari, H., J. Liu, and S. Dagogo-Jack. 2000. Hormonal regulation of human leptin in vivo: Effects of hydrocortisone and insulin. Int. J. Obes. Relat. Metab. Disord. 24:1254-1259.

Bauman, D. E. 2000. Regulation of nutrient partitioning during lactation: Homeostasis and homeorhesis revisited. Pages 311-318 in Ruminant Physiology, Digestion, Metabolism, Growth and Reproduction. Proceedings 9th International Symposium on Ruminant Physiology. P. B. Cronje, ed. Commonwealth Agricultural Bureau International, New York, NY.

Bell, A. W. 1995. Regulation of organic nutrient metabolism during transition from late pregnancy to early lactation. J. Anim. Sci. 73:2804-2819.

Blache, D., R. L. Tellam, L. M. Chagas, M. A. Blackberry, P. E. Vercoe, and G. B. Martin. 2000. Level of nutrition affects leptin concentrations in plasma and cerebrospinal fluid in sheep. J. Endocrinol. 165:625-637.

Block, S. S., W. R. Butler, R. A. Ehrhardt, A. W. Bell, M. E. Van Amburgh, and Y. R. Boisclair. 2001. Decreased concentration of plasma leptin in periparturient dairy cows is caused by negative energy balance. J. Endocrinol. 171:339-348.

Boden, G., X. Chen, M. Mozzoli, and I. Ryan. 1997. Effects of prolonged hyperinsulinemia on serum leptin in normal human subjects. J. Clin. Invest. 100:1107-1113.

Boisclair, Y. R., D. E. Bauman, A. W. Bell, F. R. Dunshea, and M. Harkins. 1994. Nutrient utilization and protein turnover in the hindlimb of cattle treated with bovine somatotropin. J. Nutr. 124:664-673.

Chilliard, Y., A. Ferlay, Y. Faulconnier, M. Bonnet, J. Rouel, and F. Bocquier. 2000. Adipose tissue metabolism and its role in adaptations to undernutrition in ruminants. Proc. Nutr. Soc. 59:127134.

Ehrhardt, R. A., R. M. Slepetis, M. E. Van Amburgh, J. Siegal-Willot, A. W. Bell, and Y. R. Boisclair. 2000. Development of a specific radioimmunoassay to measure physiological changes of circulating leptin in cattle and sheep. J. Endocrinol. 166:519-528.

Elimam, A., A. C. Lindgren, S. Norgren, A. Kamel, C. Skwirut, P. Bang, and C. Marcus. 1999. Growth hormone treatment downregulates serum leptin levels in children independent of changes in body mass index. Horm. Res. 52:66-72. 
Emilsson, V., Y. L. Liu, M. A. Cawthorne, N. M. Morton, and M. Davenport. 1997. Expression of the functional leptin receptor mRNA in pancreatic islets and direct inhibitory action of leptin on insulin secretion. Diabetes 46:313-316.

Etherton, T. D., and D. E. Bauman. 1998. Biology of somatotropin in growth and lactation of domestic animals. Physiol. Rev. 78:745-761.

Florkowski, C. M., G. R. Collier, P. Z. Zimmet, J. H. Livesey, E. A. Espiner, and R. A. Donald. 1996. Low-dose growth hormone replacement lowers plasma leptin and fat stores without affecting body mass index in adults with growth hormone deficiency. Clin. Endocrinol. 45:769-773.

Garcia, M. R., M. Amstalden, S. W. Williams, R. L. Stanko, C. D. Morrison, D. H. Keisler, S. E. Nizielski, and G. L. Williams. 2002. Serum leptin and its adipose gene expression during pubertal development, the estrous cycle, and different seasons in cattle. J. Anim. Sci. 80:2158-2167.

Griinari, J. M., M. A. McGuire, D. A. Dwyer, D. E. Bauman, and D. L. Palmquist. 1997. Role of insulin in the regulation of milk fat synthesis in dairy cows. J. Dairy Sci. 80:1076-1084.

Henry, B. A., J. W. Goding, W. S. Alexander, A. J. Tilbrook, B. J. Canny, F. Dunshea, A. Rao, A. Mansell, and I. J. Clarke. 1999. Central administration of leptin to ovariectomized ewes inhibits food intake without affecting the secretion of hormones from the pituitary gland: Evidence for a dissociation of effects on appetite and neuroendocrine function. Endocrinology 140:1175-1182.

Houseknecht, K. L., C. P. Portocarrero, S. Ji, R. Lemanager, and M. E. Spurlock. 2000. Growth hormone regulates leptin gene expression in bovine adipose tissue: Correlation with adipose IGF1 expression. J. Endocrinol. 164:51-57.

Ingvartsen, K. L., and Y. R. Boisclair 2001. Leptin and the regulation of food intake, energy homeostasis and immunity with special focus on periparturient ruminants. Domest. Anim. Endocrinol. $21: 215-250$.

Kauter, K., M. Ball, P. Kearney, R. Tellam, and J. R. McFarlane. 2000. Adrenaline, insulin and glucagon do not have acute effects on plasma leptin levels in sheep: development and characterisation of an ovine leptin ELISA. J. Endocrinol. 166:127-135.

Kolaczynski, J. W., M. R. Nyce, R. V. Considine, G. Boden, J. J. Nolan, R. Henry, S. R. Mudaliar, J. Olefky, and J. F. Caro. 1996. Acute and chronic effects of insulin on leptin production in humans: Studies in vivo and in vitro. Diabetes 45:699-701.

Kunz, T. H., E. Bicer, W. R. Hood, M. J. Axtell, W. R. Harrington, B. A. Silva, and E. P. Widmaier. 1999. Plasma leptin decreases during lactation in insectivorous bats. J. Comp. Physiol. [B] 169:61-66.

Lord, G. M., G. Matarese, J. K. Howard, R. J. Baker, S. R. Bloom, and R. I. Lechler. 1998. Leptin modulates the T-cell immune response and reverses starvation-induced immunosuppression. Nature (Lond.) 394:897-901.

Mackle, T. R., D. A. Dwyer, K. L. Ingvartsen, P. Y. Chouinard, J. M. Lynch, D. M. Barbano, and D. E. Bauman. 1999. Effects of insulin and amino acids on milk protein concentration and yield from dairy cows. J. Dairy Sci. 82:1512-1524.

Marie, M., P. A. Findlay, L. Thomas, and C. L. Adam. 2001. Daily patterns of plasma leptin in sheep: Effects of photoperiod and food intake. J. Endocrinol. 170:277-286.

McGuire, M. A., D. E. Bauman, D. A. Dwyer, and W. S. Cohick. 1995. Nutritional modulation of the somatotropin/insulin-like growth factor system: Response to feed deprivation in lactating cows. J. Nutr. 125:493-502

Miyakawa, M., T. Tsushima, H. Murakami, O. Isozaki, H. Demura, and T. Tanaka. 1998. Effect of growth hormone (GH) on serum concentrations of leptin: Study in patients with acromegaly and GH deficiency. J. Clin. Endocrinol. Metab. 83:3476-3479.

Morrison, C. D., J. A. Daniel, B. J. Holmberg, J. Djiane, N. Raver, A. Gertler, and D. H. Keisler. 2001. Central infusion of leptin into well-fed and undernourished ewe lambs: effects on feed intake and serum concentrations of growth hormone and luteinizing hormone. J. Endocrinol. 168:317-324

Morton, N. M., V. Emilsson, P. de Groot, A. L. Pallett, and M. A. Cawthorne. 1999. Leptin signaling in pancreatic islets and clonal insulin-secreting cells. J. Mol. Endocrinol. 22:173-184.

National Research Council 1989. Nutrient Requirements of Dairy Cattle. 6th rev. ed. Natl. Acad. Sci., Washington, DC.

Peel, C. J., T. J. Fronk, D. E. Bauman, and R. C. Gorewit. 1983. Effect of exogenous growth hormone in early and late lactation on lactational performance of dairy cows. J. Dairy Sci. 66:776-782.

Pickavance, L., M. Tadayyon, G. Williams, and R. G. Vernon. 1998. Lactation suppresses diurnal rhythm of serum leptin. Biochem. Biophys. Res. Commun. 248:196-199.

Saladin, R., P. De Vos, M. Guerre-Millo, A. Leturque, J. Girard, B. Staels, and J. Auwerx. 1995. Transient increase in obese gene expression after food intake or insulin administration. Nature (Lond.) 377:527-529.

Schwartz, M. W., S. C. Woods, D. Porte, Jr., R. J. Seeley, and D. G. Baskin 2000. Central nervous system control of food intake. Nature (Lond.) 404:661-671.

Spiegelman, B. M., and J. S. Flier. 2001. Obesity and the regulation of energy balance. Cell 104:531-43.

Terada, Y., K. Yamakawa, A. Sugaya, and N. Toyoda. 1998. Serum leptin levels do not rise during pregnancy in age-matched rats. Biochem. Biophys. Res. Commun. 253:841-844.

Thomas, L., J. M. Wallace, R. P. Aitken, J. G. Mercer, P. Trayhurn, and N. Hogard. 2001. Circulating leptin during ovine pregnancy in relation to maternal nutrition, body composition and pregnancy outcome. J. Endocrinol. 169:465-476. 